Dicle Tıp Dergisi / Dicle Medical Journal (2017) 44 (4) : 373-380

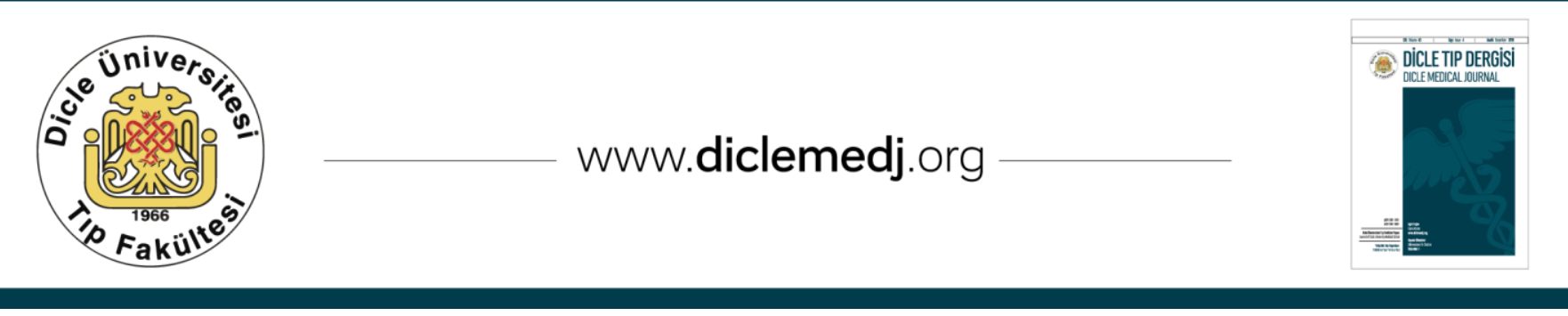

Özgün Araștırma / Original Article

\title{
Mikroenkapsüle edilen paratiroid hücrelerinin in-vitro optimizasyonu
}

\author{
Emrah Yücesan1, Harun Başoğlu², Beyza Göncü ${ }^{3}$, Nur Özten Kandaş, \\ Yeliz Emine Ersoy ${ }^{5}$, Fahri Akbaş6, Erhan Ayșan ${ }^{5}$
}

1 Bezmialem Vakıf Üniversitesi, Yaşam Bilimleri ve Biyoteknoloji Enstitüsü, İstanbul, Türkiye ORCID: 0000-0003-4512-8764 2 Bezmialem Vakıf Üniversitesi, Tıp Fakültesi, Biyofizik Anabilim Dal, İstanbul, Türkiye ORCID: 0000-0002-0853-028X

3 Bezmialem Vakıf Üniversitesi, Deneysel Uygulama ve Araștırma Merkezi, İstanbul, Türkiye ORCID: 0000-0001-6026-8218

4 Bezmialem Vaklf Üniversitesi, Eczaclllk Fak., Farmasötük Toksikoloji Anabilim Dall, İstanbul, Türkiye ORCID: 0000-0002-0441-8397

5 Bezmialem Vakıf Üniversitesi, Tıp Fakültesi, Genel Cerrahi Anabilim Dall, İstanbul, Türkiye ORCID: 0000-0002-5028-6436

5 Bezmialem Vakıf Üniversitesi, Tıp Fakültesi, Genel Cerrahi Anabilim Dal, İstanbul, Türkiye ORCID: 0000-0002-3837-250X

6 Bezmialem Vakıf Üniversitesi, Tıp Fakültesi, Tıbbi Biyoloji Anabilim Dalı, İstanbul, Türkiye ORCID: 0000-0002-9563-3761

Geliş: 17.08.2017, Revizyon: 26.09.2017, Kabul Tarihi: 05.10.2017

\section{Özet}

Amaç: Enkapsülasyon, bir maddenin ya da bir karışımın diğer bir malzeme ya da sistemle kaplandığı ya da içine sıkıştırıldığı tekniktir. Mikroenkapsülasyon tekniği, tıp dahil olmak üzere pek çok farklı disiplin tarafından uygulanmaya çalışılan ve halen en uygun enkapsülasyon tekniğinin bulunması için araştırmaların yürütüldüğü bir tekniktir. Mikroenkapsülasyon tekniğinde birbirinden farklı maddeler uygulanabilir. Bu maddeler elde edilme kaynaklarına göre doğal ya da sentetiktir. Mikroenkapsülasyon tekniği tıp pratiğinde özellikle pankreas beta hücrelerinin, Tip 1 Diabetes Mellitus (DM) hastalarına verilmesinde kullanılmaktadır. Mikroenkapsülasyonun uygulandığı bir başka durum ise hipoparatiroidi tanılı hastalara paratiroid hücrelerinin verilmesidir. Paratiroid hücrelerinin, mikroenkapsülasyon işleminde kullanılabilebilmesinin en önemli özelliklerinden biri, hücrelerin görece homojen yapıda olmaları, eksikliğinin organizmada doğrudan gözlemlenebilir semptomlara neden olması dolayısıyla oluşacak yanitın hızlıca belirlenebilmesidir.

Yöntemler: Çalıșmamızda paratiroidhiperplazisi tanısı almıș insandan elde edilen paratiroid dokularından izole edilen hücreler, \%2'lik ultra saf aljinat ile muamele edildi. İşlem sırasında her bir kapsül sayısı hesaplandı ve kapsül başına 5X106, 10X106, 20X106 ve 50X106 hücre eklendi. Sonrasında 75 gün boyunca içlerinde paratiroid hücresi bulunan kapsüllerin morfolojik özellikleri ve parathormonsekresyon yeteneklerinin zaman bağlı değişimi gözlemlendi.

Bulgular: 75 gün sonrasında tüm gruplar için korele olarak parathormon düzeyinde düșüş tespit edildi. Kapsüler formasyonda ciddi bir bozulmanın görülmediği grup, 20X106 hücre uygulanan grup oldu.

Sonuç: Çalışmamızda model olarak değerlendirdiğimiz paratiroid hücrelerinin kapsülasyonu için en uygun koşulları (kapsülasyonda kullanılacak madde, destekleyici tampon, uygulanan maddelerin yüzdeleri, miktarları) belirlendi. Ayrıca günlere bağlı olarak kapsüllerdeki bozulmalar da tespit edildi. İlerleyen çalışmalarda optimize ettiğimiz koşulların hipoparatiroidizm tanılı hasta gruplarında denenmesi ve sonuçların burada sunduğumuz in vitro deney sonuçları ile karşılaştırılması gerekmektedir.

Anahtar kelimeler: Mikroenkapsülasyon, ultrasafaljinat, paratiroid hücreleri, hipoparatiroidizm

DOI: 10.5798 /dicletip.362435

Yazışma Adresi / Correspondence: Emrah Yücesan, Bezmialem Vakıf Üniversitesi, Adnan Menderes Bulvarı Vatan Caddesi 34093 Fatih-İstanbul, Türkiye e-mail: eyucesan@bezmialem.edu.tr 


\title{
In-vitro optimization of microencapsulated parathyroid cells
}

\begin{abstract}
Objective: Encapsulation is a process that a mixture combined and coated with another material or system. Microencapsulation has been the most frequently used technique for several different disciplines and it is still a common technique in which researches are carried out to detect the most appropriate encapsulation technique. Different substances can be applied for this technique. Applied materials have positive and negative potencies. Microencapsulation technique is used in medicine, particularly pancreatic $\beta$-cells are given for treating Type 1 Diabetes Mellitus (DM) patients. Another research field of technique have been investigated for the treatment of the patients which diagnosed with permanent hypoparathyroidsm with the advantage of via capsulated parathyroid cell transplantation and as a result the improvement of parathormone levels also amelioration of the clinical symptoms who prevents the graft versus host reaction to the transplanted cells as a consequences of capsulation process. The most important characteristics of parathyroid cells includes relatively a homogenous population and in the absence, symptoms are directly observable therefore microencapsulation process made them useful for determination of results.

Methods: In this study isolated parathyroid tissue cells, which were mixed with $2 \%$ ultrapure alginate, from a patient diagnosed with parathyroid hyperplasia were used. During this process capsule quantity for each cell/capsule groups of 5X106, 10X106, 20X106and 50X106 were calculated. Afterwards each capsulated parathyroid cell groups were evaluated with their altered morphological features and parathormone release ability for 75 days.

Results: Throughout 75 days, gradual decrease in parathormoneleves for each group was evaluated. In particular 20X106 cells with capsulated group were stable for capsulary formation.

Conclusion: In our study, the optimal conditions (substance for capsulation, supporting medium, percentage and amounts of material) for encapsulation of parathyroid cells (as a model) were determined. In addition, deterioration in the capsules was detected depending on the days. It is necessary for further investigations to test the conditions we optimized. Similar conditions should be evaluate with the patients have hypoparathyroidism and compare with the in vitro test results we provide here.
\end{abstract}

Keywords: Microencapsulation, ultrapure alginate, parathyroid cells, hypoparathyroidism

\section{GíRIŞ}

Enkapsülasyon, bir maddenin ya da bir karıșımın diğer bir malzeme ya da sistemle kaplandığı ya da içine sıkıştırıldığı tekniktir, bu sayede kaplanmış malzemeye aktif veya çekirdek malzeme ve kaplama malzemesine ise taşıyıcı veya kapsülleyici (enkapsülant) denir ${ }^{1}$. Günümüzde enkapsülasyon tekniği, farmasötik, kimya, kozmetik ve besin endüstrisi gibi dallarda geniş uygulama alanına sahiptir².

Bir enkapsülasyon tekniği olan mikroenkapsülasyon ise etken maddenin diş ortamdan korunmasına, istenmeyen bileşenlerin maskelenmesine, bunların yanında bileşiklerin kontrollü salınımına izin veriri3.Bunu da küçük parçacıkların veya damlacıkların bir çeşit kaplama materyali ile çevrelenmesi ve homojen ya da heterojen bir matrise gömülü olmasıyla gerçekleştirir. Bu sayede, ana bileşik ile ürünün diğer bileşenleri arasında fiziksel bir bariyer oluşumu sağlanır ${ }^{4}$. Mikroenkapsülasyon uygulamak için doğal (aljinat tabanlı, jelatin tabanlı, selüloz tabanlı ve kitosan tabanlı) ya da sentetik, (sodyum aljinat, poli-L-ornitin (PLO), gliklazidaljinat, poli-laktik-ko-glikolik asit (PLGA) aljinat, kollajen, selüloz, polietilen glikol (PEG), grafen oksit-FTY720 (GO-FTY720), polivinilalkol (PVA), poli- $\varepsilon$-kaprolakton (PCL), polimetil metakrilat (PMAA) ve sodyum polisitren gibi) pek çok materyal kullanılmaktadır ${ }^{5,6}$. Bunlar arasindan aljinat; kahverengi algden elde edilen doğal anyonik ve biyouyumlu bir polimerdir. Ham haldeki aljinat saflaştırıldıkça mekanik anlamda stabil yapı kazanmasının yanında berraklığı ve en önemlisi biyouyumlu 
polimer özellikleri artış gösterir7 ${ }^{7}$ Alginat; kalsiyum, baryum, stronsiyum gibi divalent katyonlar varlığında, polimer yapısı içerisinde bulunan glukronik asit bloklarının iç zincirleri arasında iyonik bağ oluşturması ile kapsüle hale gelirler. Yüksek miktarda glukronik asit içeren aljinat polimerleri mekanik anlamda daha sert ve stabilitesi yüksek yapılar oluşturur $^{8}$. Aljinatın daha saf hali olan ultrasafaljinat; içerdiği glukronik asit blokları sayesinde yüksek biyouyumluluğu ile özellikle insanla gerçekleştirilen çalışmalarda tercih edilir6. Bunun en önemli nedeni ultrasafaljinatın, organizmada oluşabilecek olası bir immün yanıttan, oluşturduğu bariyer sayesinde etkilenmemesidir ${ }^{9}$. Tüm bu özellikler birlikte değerlendirildiğinde aljinat tabanlı mikroenkapsülasyon tekniğinin taşıyıcı veya aracı bir sistem gibi özellikle nakil ve benzeri araştırmalarda, kullanılabilirliğini ortaya koymaktadır. Farmasötik ve biyomedikal alanlardaki teknolojik gelişimler, aljinat mikropartiküllerinin ilaç taşıyıcı veya hücre nakli için yüksek potansiyele sahip olduğunu göstermektedir ${ }^{10,11}$. İnsanda mikroenkapsülasyon yöntemi özellikle diyabetli olgulardaki pankreas adacık naklinde yoğun olarak çalışılmaktadır ${ }^{12}$. Diyabet hastalığının tedavisine yönelik gerçekleştirilen ve mikroenkapsülasyonun yöntem olarak kullanıldığ çalışmalar, özellikle diyabetin otoimmün tipi olan ve Langerhans adacıklarındaki insülin üreten $\beta$ hücrelerinin harabiyetiyle ortaya çıkan bir patoloji olan Tip $1 \mathrm{DM}$ hastalığına yoğunlaşmıştır ${ }^{13}$. Literatürde ayrıca, mikroenkapsülasyon yöntemi ile kapsüle edilen çeşitli ilaçlara ek olarak ${ }^{11}$, kök hücreler ${ }^{14} v e$ paratiroid dokusundan izole edilen hücrelerin de kullanıldığı gösterilmiştir ${ }^{15,16}$. Çalışmamızda uzun senelere dayanan paratiroid hücreleri ile gerçekleştirdiğimiz çalışmalarımızdan gelen bulgularımızı dikkate alarak, mikroenkapsülasyon tekniğinin optimum koşullarını sağlamak için bu hücreleri model olarak kullandık.

\section{YÖNTEMLER}

Çalışmada paratiroid dokusundan izole edilen ve sonrasında mikroenkapsülasyon işlemine tabii tutulan paratiroid hücreleri kullanılmıştır. Mikroenkapsüle edilen hücrelerin sayısı, şekli ve canlılık durumları ile mikroenkapsüllerin sayısı, sonrasında elde edilen parathormon miktarı ölçülmüştür.

\section{Paratiroid Hücrelerinin İzolasyonu}

Yaklaşık 0,8-1,0 gr. ağırlığındaki hiperplazik paratiroid dokuları bir petri kabına alınarak iki defa 1X PBS ile yıkandı. Doku petri kabı üzerindeyken, bistüri yardımıyla küçük parçalara ayrıştırıldı. Temiz bir petri kabına aktarlan dokunun üzerine $1 \mathrm{ml}$ Kollajenaz (215 $\mu \mathrm{mol}), 300 \mu \mathrm{l}$ Dnaz $(0,32 \mu \mathrm{M}), 200 \mu \mathrm{l}$ BSA $(100 \mu \mathrm{g} / \mathrm{ml})$ ve $500 \mu \mathrm{l}$ HEPES-Ham's F10 eklendi ve 370C'de \%5 CO2 içeren inkübatörde 18 saat boyunca inkübe edildi. İnkübatörden çıkarılan doku parçaları üzerine McCoy's 5A hücre kültür medyumu (\%10 FBS, \%1 P/S ve \%1 NEAA içeren) eklenerek enzim inaktive edildi. Sonrasında pipetaj yapılarak homojenize doku parçaları $70 \mu \mathrm{m}$ 'lik cell-strainer'dan (Falcon, BD Biosciences, NJ, USA) geçirildi ve 1400 rpm'de oda sicaklığında 12 dakika santrifüj edildi. İşlem sonrasında üst faz dökülerek altta kalan pellet kısmı McCoy's 5A kültür medyumu ile homojen hale getirildi. $\mathrm{Bu}$ hücre süspansiyonundan sayım için gereken miktar Muse Hücre analiz cihazında (Merck Millipore, Germany) kullanıldı. Kalan kısım kapsülasyon prosedürü için hazırlandı.

\section{Mikroenkapsülasyon Prosedürü}

Paratiroid dokularından elde edilen hücreler McCoy's 5A medyumunda 24 saat boyunca kültüre edildi. Sonrasında hücreler izotonik tuz çözeltisinde, 1400 rpm'de 12 dakika santrifüj edilerek kültür medyumu yıkandı. Hücrelerin canlılık oranları ve sayıları belirlendi (Şekil 1).

\%2'lik ultra saf aljinat (Pronova UP MVG; Nova Matrix, Oslo, Norway) hazırlandı ve sterilize edildi. Çalışmadaki gruplar 5x106, 10x106, 
20x106, 50x106 hücre sayısı içerecek şekilde oluşturuldu. Aljinat içerisindeki izotonik tuz çözeltisi+hücre sayısı oranı \%30 olacak şekilde ayarlandı. Aljinat hücre karışımı 30G şırınga ile 300 mOsm CaCl2 içeren çözeltiye yaklaşık 20 cm yükseklikten yavaşça damlatıldı. Damlatılan kapsül sayıları tüm gruplar için kaydedildi. Bağlı olmayan kalsiyumun ortamdan uzaklaştırılması için mikroenkapsüller izotonik tuz çözeltisi ile yıkandı. Elde edilen mikroenkapsüllerin çapları 2,2-2,3 mm olarak ölçüldü.
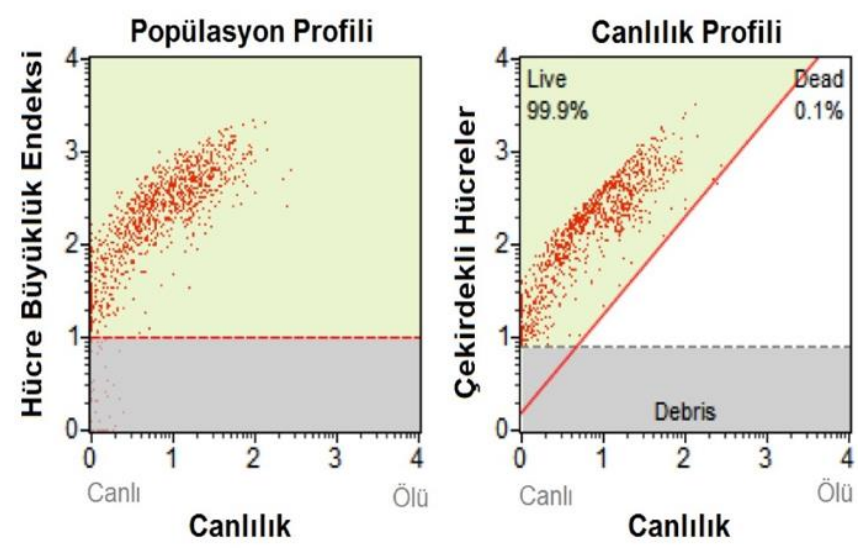

Şekil 1: Mikroenkarpsüle edilen paratiroid hücrelerinin canlılık profilleri ve oranları

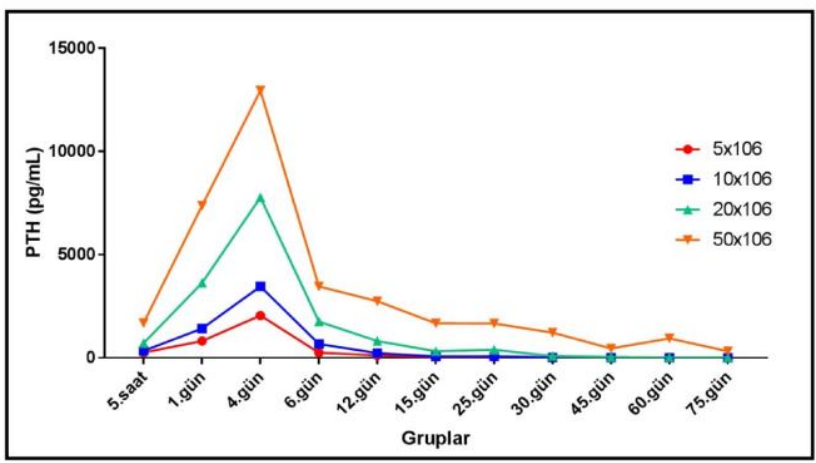

Şekil 2: 75 gün boyunca takip edilen mikrokapsüllerden salınan PTH miktarı. PTH: Parathormon

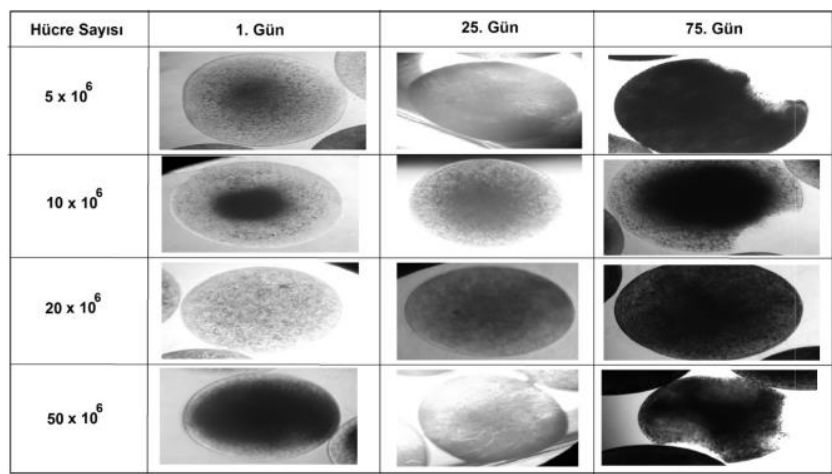

Şekil 3: Mikrokapsüllerin, kapsüle edilen hücre sayılarına göre ışık mikroskobu görüntüleri

Mikroenkapsüllerin Takibi ve Parathormon ölçümü

Kapsül içeren tüm gruplarda, 5. saat ilk örnek toplanma süresi olarak ve 1., 4., 6., 12., 15., 25. 45., 60., 75. günlerde parathormon için medyum örnekleri toplandı ve kapsüller izotonik tuz çözeltisi ile yıkanarak medyumları değiștirildi.

Parathormon ölçümleri, PTH EIA kit (RayBiotechInc., GA, USA) protokolüne göre ve absorbansı $450 \quad$ nm'dei Mark Microplate Absorbance Reader (Bio-Rad, USA) kullanılarak ölçüldü.

\section{BULGULAR}

Mikroenkapsüle edilen paratiroid hücrelerinin parathormon seviyeleri ilk olarak beşinci saatte, sonraki ölçüm ise 24 . saatte gerçekleştirildi. Bu ilk ölçümleri takip eden sonraki ölçümler 75. güne kadar devam etti ve parathormon seviyelerindeki değişimler, uygulanan mikroenkapsüllerin sayısı da dikkate alınarak değerlendirildi (Tablo 1). Her dört grup için de (hücre sayıları sırasıyla, 5X106, 10X106, 20X106, 50X106) parathormon seviyelerinin birbirleriyle uyumlu olacak şekilde dördüncü günde maksimum düzeye ulaştığı, sonrasında ise düzenli bir şekilde azaldığı belirlendi (Şekil 2). Mikroenkapsüllerin morfolojilerinde izlem süresince bozulma, çatlama ve en sonunda parçalanma tespit edildi (Şekil 3). Morfolojide meydana gelen bu 
değişimler en yoğun olarak 5X106 ve 50X106

hücre içeren gruplarda tespit edildi.

Tablo 1. Hücre ve mikrokapsül sayılarına göre parathormon düzeylerinin 75 günlük izlem sonuçlarına göre değiş̧imi. PTH: Parathormon

\begin{tabular}{|c|c|c|c|c|c|c|c|c|c|c|c|c|}
\hline Kapsül sayısı & ücre sayısı & $\begin{array}{l}\text { 5. saat } \\
\text { PTH } \\
(\mathrm{pg} / \mathrm{ml})\end{array}$ & $\begin{array}{l}\text { 24. saat } \\
\text { PTH } \\
(\mathrm{pg} / \mathrm{ml})\end{array}$ & $\begin{array}{l}\text { 4. gün } \\
\text { PTH } \\
\text { (pg/ml) }\end{array}$ & $\begin{array}{l}\text { 6. gün } \\
\text { PTH } \\
\text { (pg/ml) }\end{array}$ & $\begin{array}{l}\text { 12. gün } \\
\text { PTH } \\
(\mathrm{pg} / \mathrm{ml})\end{array}$ & $\begin{array}{l}\text { 15. gün } \\
\text { PTH } \\
\text { (pg/ml) }\end{array}$ & $\begin{array}{l}\text { 25. gün } \\
\text { PTH } \\
(\mathrm{pg} / \mathrm{ml})\end{array}$ & $\begin{array}{c}\text { 30. gün } \\
\text { PTH } \\
(\mathrm{pg} / \mathrm{ml})\end{array}$ & $\begin{array}{l}\text { 45. gün } \\
\text { PTH } \\
(\mathrm{pg} / \mathrm{ml})\end{array}$ & $\begin{array}{l}\text { 60. gün } \\
\text { PTH } \\
(\mathrm{pg} / \mathrm{ml})\end{array}$ & $\begin{array}{l}\text { 75. gün } \\
\text { PTH } \\
\text { (pg/ml) }\end{array}$ \\
\hline 45 & $5 \times 10^{6}$ & 259 & 821 & 2050 & 244 & 120 & 43 & 57,5 & 23 & 13,9 & 12,5 & 11,8 \\
\hline 40 & & 263 & 878 & 2065 & 253 & 101 & 34 & 56,1 & 23,8 & 11,5 & 11,5 & 8,5 \\
\hline 42 & & 250 & 1076 & 2475 & 323 & 144 & 47 & 61,7 & 38,3 & 16,7 & 15,1 & 11,3 \\
\hline 42 & $10 \times 10^{6}$ & 340 & 1425 & 3457 & 675 & 228 & 68 & 71,7 & 22 & 12,4 & 8,8 & 6,8 \\
\hline 41 & & 357 & 1826 & 4263 & 616 & 224 & 67 & 51,5 & 25,9 & 11,6 & 7,6 & 5 \\
\hline 38 & & 349 & 2049 & 3712 & 424 & 148 & 45 & 57,9 & 25,2 & 12,5 & 9,2 & 8,6 \\
\hline 43 & $20 \times 10^{6}$ & 712 & 3630 & 7776 & 1754 & 814 & 317 & 395,6 & 87 & 38,3 & 26,5 & 20,1 \\
\hline 39 & & 780 & 3235 & 6072 & 1890 & 1208 & 449 & 567,6 & 89,2 & 27,4 & 17 & 21,6 \\
\hline 39 & & 856 & 3781 & 6279 & 1730 & 896 & 364 & 482,4 & 118,8 & 32,3 & 18,6 & 27,6 \\
\hline 41 & $50 \times 10^{6}$ & 1686 & 7379 & 12960 & 3462 & 2749 & 1670 & 1661 & 1225 & 459,9 & 944 & 321,2 \\
\hline 34 & & 1903 & 8696 & 7101 & 3265 & 2733 & 1854 & 1930 & 1879,5 & 510,9 & 934 & 271,2 \\
\hline 37 & & 1618 & 8580 & 11301 & 3254 & 2355 & 1191 & 1095,5 & 886,5 & 373,5 & 795 & 280,8 \\
\hline
\end{tabular}

TARTIŞMA

Bileşenlerin konuldukları ortamdan bir bariyer ile ayrılmaları ve bu durumdayken işlevselliklerini kaybetmemelerini sağlayan mikroenkapsülasyon tekniği uzun süredir bilinmektedir 17,18 ve birçok farklı disiplin tarafindan kullanılmaktadır ${ }^{19}$. Bu kapsamda probiyotikleri içeren araştırmalar literatürde mevcuttur ${ }^{20}$. $\mathrm{Bu}$ çalışmaların ilki Lactobacillusparacasei'nin hücreleri mikroenkapsüle edilerek fermentasyon üzerine etkileri araştırılmış ve kapsülasyon için gereken en uygun kondisyonlar belirlenmeye çalışılmıştır (süre, pH değeri vb.) ${ }^{20}$. Bahsedilen diğer bir çalışmada ise insan sağlığı için yararlı olduğu bilinen iki farklı bakteri suşunda mikroenkapsülasyon işlemi gerçekleștirilmiş; uygun hücre canlılığı, sayısı ve kapsüllerin en uygun çapları gösterilmiştir.

İnsan sağlığını da ilgilendiren biyomedikal araștırmalarda mikroenkapsülasyon tekniğinin uygulanması özellikle ilaç salınımının düzenlenmesi amacıyla ele alınmaktadır. 2014 senesinde yayımlanan bir derlemede mikroenkapsülasyon tekniğinin oral ve transdermal yollarla uygulanmaları halinde görülen verimlilik farkı in vivo ve invitro olarak analiz edilmiştir ${ }^{21}$. Bahsedilen yayında ayrıca mikroenkapsülasyon tekniklerinin farklı tipleri de doğal ve (aljinat tabanl,, jelatin tabanl,, selüloz tabanlı ve kitosan tabanlı) ve sentetik (PLO, PLGA, aljinat, kollajen, selüloz, PEG, GOFTY720, PVA, PCL, PMAA, sodyum polisitren gibi) mikroenkapsülasyon uygulamaları olarak ayrıntılı şekilde ele alınmış ve her yaklaşımın ayrı ayrı güçlü-zayıf yanları ortaya konmuştur. Diğer çalışmalarda mikroenkapsülasyon tekniğinin hali hazırda kullanımda olduğu ancak özellikle ilaç salınımı gibi süreçlerde yeterli doz oranlarının ve kapsül özelliklerinin düzenlenmesi gerektiğinden bahsedilmektedir ${ }^{22}$. Mikroenkapsülasyon tekniğinin insan 
sağlı̆̆ını doğrudan ilgilendiren bir diğer kullanım alanı, bir otoimmün hastalık olan ve Langerhans adacıklarında bulunan $\beta$ hücrelerinin hasarı sonucunda glisemik kontrolün bozulduğu Tip 1DM hastalığının tedavisidir13,23,24. DM tedavisinde, özellikle odaklanılan araştırma alanı pankreastaki $\beta$ hücrelerinin mikroenkapsüle edilerek hastaya verilmesidir. $\mathrm{Bu}$ çalışmalarda da henüz optimize bir kapsülasyon yöntemi ve uzun dönemli klinik izlem parametreleri mevcut değildir ${ }^{24}$. Ancak yine de teknik farklı şekillerde değerlendirilerek görece başarılı sonuçlar elde edilmektedir. Long $\mathrm{R}$. ve ark. tarafindan gerçekleştirilen bir çalışmada kök hücrelerin somatik hücrelerle birlikte kültüre edilip sonrasında kapsüle edilmeleriyle Tip 1 DM tedavisinde anlamlı sonuçlar elde edildiği fakat optimizasyon süreçlerinin zorluklarından bahsedilmiştir ${ }^{13}$. Sadece optimizasyon sorununu aşmak için gerçekleştirilen ve konfokal mikroskobu ile de desteklenen bir mikroenkapsülasyon çalışmasında mikroçevrenin ve kapsüle edilen hücrelerin canlılığının kapsülasyon sürecindeki öneminden bahsedilmiş ve uygulama açısından kısıtlayıcı unsurlar bulunduğuna değinilmiştir. Mikroenkapsülasyon tekniğinin bir diğer uygulaması da paratiroid hücrelerinin kullanımıdır. Literatürde ilk defa 1987 senesinde in vitro çalışma olarak paratiroid hücrelerinin mikroenkapsüle edilmesinden bahsedilmektedir ${ }^{25}$. İlerleyen yıllarda kalıcı hipoparatiroidizm hastalığı ile mücadele etmek için paratiroid hücrelerinin kapsüle edilerek etkilenmiş sıçanlara verilmesi denenmiştir. Bu amaçla kapsülasyonda kullanılan malzeme mitojenik özellikte olmayan baryum aljinat olarak seçilmiştir ${ }^{26}$. Özellikle immün sistemden kaçış aracı olarak kullanılan mikroenkapsülasyon tekniği 1998 senesinde, bu özelliğinin sınanması için zenotransplantasyon işlemi ile denenmiştir ${ }^{27}$. Insan dokusunun, total paratiroidektomi işlemi uygulanan 40 siçana verilmesi sonucunda tüm sıçanların normokalsemik hale geldiği gösterilmiştir ${ }^{27}$.
Gerçekleştirilen bir başka hayvan çalışmasında ise 10 adet yeni doğan domuzdan elde edilen paratiroid hücrelerinin aljinat-polilizin-aljinat (APA) ile mikroenkapsüle edilip sıçanlara verilmesi ve 40 haftalı takibi gerçekleştirilmiştir. Çalışma sonrasında in-vivo ortamda \%0,9'lukNaCl uygulanması halinde bu sonucun elde edildiği bildirilmiş ve diğer kondisyonlardan bahsedilmemiştir ${ }^{28}$. Tamamen mikroenkap-sülasyon işleminin optimizasyonunun sağlanması için gerçekleştirilen bir çalışmada, paratiroid hücreleri \%1,5'luk aljinat ve $\mathrm{CaCl} 2$ çözeltisi, 18G enjektör yardımıyla ve +40C'de kullanıldığında maksimum verimin in vitro olarak elde edildiği bildirilmiştir ${ }^{29}$. İnsanda gösterilen bir vaka çalışmasında ise ${ }^{15}$ tiroidektomi ameliyatı sonrası gelișen hipoparatiroidizm tanılı bir hastaya mikroenkapsüle edilmiş paratiroid hücreleri, ön kola $10 \mathrm{~cm}$ 'lik kesi açılarak verilmiş ve sonrasında 20 ay boyunca gözlemlenmiştir. $\mathrm{Bu}$ çalışma sırasında da tıpkı benzeri çalışmalarda olduğu gibi bir çok parametre için optimizasyon denenmiştir. Mikroenkapsülasyon işlemi için \%2'lik sodyum aljinat kullanılmış, baryum klorür solüsyonuna (115 $\mathrm{mmol} / \mathrm{L} \mathrm{NaCl}$ içerisine $20 \mathrm{mmol} / \mathrm{L}$ ) hücre aljinat karışımı damlatılarak kapsüle edilmiş, $\% 0,85$ 'lik $\mathrm{NaCl}$ ile yıkanmış ve sonrasında baryumdan arındırmak için Na2SO (2 mmol/L) ile muamele edilmiştir. Benzer şekilde sonraki inkübasyon aşamaları da en uygun koşulların tespiti için araştırılmıştır ${ }^{15} .2016$ senesinde yayınlanan bir başka çalışmada ise PTH (1-34) ile lizine bağlı deoksikolik asit (LysDOCA) arasında iyonik nanokompleks oluşturulup oral yoldan uygulanması incelenmiştir ${ }^{30}$. Bu çalışmada kompleks oluşturulurken kullanılan PTH (1-34), parathormonun N-terminal bölgesine sahip amino asit dizisinden oluşan kısımdır, yani optimizasyon çalışması, diğer bir çok değişken gibi parathormonun yapısının korunması şeklinde de olmaktadır. Son olarak 2017 senesinde yayınlanan bir çalışmada sekonder hipoparatiroidizm tanısı almış bir 
hastaya nakil yapılan hücre-mikroenkapsül işleminin 18 aylık sonuçları bildirilmiştir ${ }^{16}$. Bahsedilen çalışmanın enkapsülasyon protokolünde de görülebileceği gibi nakli yapılan dokunun immün-korunma alanına sahip olması, dokunun beslenmesi için gerekli besinlerin geçişinin sağlanması ile canlılık ve fonksiyonel devamlılık sağlandığı gösterilmiştir ${ }^{16}$.

Yukarıda açıklandığı haliyle genel olarak mikroenkapsülasyon çalışmalarının serüvenine bakıldığında, en uygun ve verimli koşulların halen net olarak tespit edilemediği görülmektedir. Önceki çalışmalarda pek çok parametre incelenmesine rağmen yapısal farklılıklara sahip biyouyumlu aljinat polimerlerinin tipi, saflık derecesi, kapsülasyon aşaması için kullanılan divalent katyon seçimi, aynı zamanda mikroenkapsüle edilmesi planlanan total hücre sayısı ve bu kapsüllerin zamana bağlı fiziksel değişiminin takibinde net protokoller bulunmamaktadır.

Sunduğumuz çalışmada, model olarak seçtiğimiz paratiroid dokusuna ait hücreleri kullanarak; hücre sayısı, hücre canlılığı, mikrokapsül sayısı, mikrokapsül çapı, mikrokapsüllerin bozulma süreci ve süresi ile mikroenkapsüle edilen molekülün (parathormon) zamana bağlı miktarı ve işlevselliğinin ne kadar devam ettiği değerlendirilerek optimum koşullar tespit edilmiştir. İlerleyen çalışmalarda belirlenen optimum şartlara göre in vivo çalışmaların yapılması, belirlediğimiz koşulların kontrol edilmesini sağlayacaktır.

Çıkar Çatışması Beyanı: Yazarlar çıkar çatışması olmadığını bildirmişlerdir.

Finansal Destek: Bu çalışma her hangi bir fon tarafından desteklenmemiştir.

Declaration of Conflicting Interests: The authors declare that they have no conflict of interest.
Financial Disclosure: No financial support was received.

\section{KAYNAKLAR}

1. Madene A, Jacquot $M$, Scher J, et al., Flavouren capsulation and controlled release - a review. Int J Food Sci Tec 2006;41:1-21.

2. Heinzen C, Microencapsulation solve time dependent problems for food makers. Europ. Food and Drink Rev. 2002;3:27-30.

3. Paulo F, Santos L, Design of experiments for microencapsulation applications: A review. Mater Sci Eng C Mater BiolAppl, 2017;77:1327-40.

4. Gharsallaoui A, Roudaut G, Odile C, et al. Applications of spray-drying in microencapsulation of food ingredients: An overview, Food Res. Int.2007;40:110721.

5. Mooranian A, Negruli R, Mathavan S, Stability and Release Kinetics of an Advanced Gliclazide-Cholic Acid Formulation: The Use of Artificial-Cell Microencapsulation in Slow Release Targeted Oral Delivery of Antidiabetics. J PharmInnov. 2014;9:150-7.

6. de Vos P, Lazarjani HA, Poncelet D, et al.,Polymers in cellencapsulation from an enveloped cell perspective. Adv Drug Deliv Rev, 2014;67-68:15-34.

7. Becker TA, Kipke DR, Brandon T, et al.,Calciumalginate gel: a biocompatible and mechanically stable polymer for endovascular embolization. J Biomed Mater Res, 2001;54:76-86.

8. Holme HK, Lindmo K, Kristiansen A, et al.,Thermal depolymerization of alginate in the solid state. Carbohydr Polym, 2003;54:431-8.

9. Gasperini L, Mano JF, Reis RL, Natural polymers for the microencapsulation of cells. J R Soc Interface, 2014:11;20140817.

10. AgüeroL, Zaldivar-Silva D, PeñaL, et al., Alginate microparticles as oral colon drug delivery device: A review. Carbohydr Polym, 2017;168:32-43.

11. Al-Kasmi B, Alsirawan MB, Bashimam M, et al., Mechanical microencapsulation: The best technique in taste masking for the manufacturing scale - Effect of polymeren capsulation on drug targeting. J Control Release, 2017;260:134-41.

12. Woodhams L, Al-Salami H, Theroles of bile acids and applications of microencapsulation technology in treating Type 1 diabetes mellitus. Ther Deliv, 2017;8:401-9.

13. Long R, Liu Y, Wang S, et al., Co-microencapsulation of BMSC sand mouse pancreatic $\beta$ cells for improving 
the efficacy of type I diabetes therapy. Int J Artif Organs, 2017;40:169-75.

14. Cañibano-Hernández A, Saenz Del Burgo L, EsponaNoguera A, et al., Alginate Microcapsules Incorporating Hyaluronic Acid Recreate Closer in Vivo Environment for Mesenchymal Stem Cells. Mol Pharm, 2017; 14: 2390-9.

15. Cabané P, Gac P, Amat J, et al., Allotransplant of microencapsulated parathyroid tissue in severe postsurgical hypoparathyroidism: a case report. Transplant Proc, 2009;41:3879-83.

16. Toledo PC, Rossi RL, Caviedes P, Microencapsulation of Parathyroid Cells for the Treatment of Hypoparathyroidism. Methods MolBiol, 2017; 1479: 357-63.

17. Luzzi LA, Microencapsulation. J PharmSci, 1970; 59: 1367-76.

18. Chang TM, Stabilisation of enzymes by microencapsulation with a concentrated protein solution or by microencapsulation followed by crosslinking with glutaraldehyde. Biochem Biophys Res Commun, 1971;44:1531-6.

19. Singh MN, Hemant KS, Ram M, et al., Microencapsulation: A promising technique for controlled drug delivery. Res Pharm Sci, 2010;5:65-77.

20. Bosnea LA, Moschakis T, Biliaderis CG, Microencapsulated cells of Lactobacillus paracasei subsp. paracasei in biopolymer complex coacervates and their function in a yogurt matrix. Food Funct, 2017; 8: 554-62.

21. Lam PL, Gambari R, Advanced progress of microencapsulation technologies: in vivoand in vitro models for studying oral and transdermal drug deliveries. J Control Release, 2014;178:25-45.

22. Bale S, Khurana A, Reddy AS, et al., et al., Overview on Therapeutic Applications of Microparticulate Drug
Delivery Systems. Crit Rev Ther Drug Carrier Syst, 2016;33:309-61.

23. Calafiore R, Basta G, Montanucci P, Microencapsulation of Islets for the Treatment of Type 1 Diabetes Mellitus (T1D). Methods MolBiol, 2017; 1479: 283-304.

24. Omami M, McGarrigle JJ, Reedy $M$, et al., Islet Microencapsulation: Strategies and Clinical Status in Diabetes. CurrDiabRep, 2017;17:47.

25. Darquy S, Sun AM, Microencapsulation of parathyroid cells as a bioartificial parathyroid. Invitrostudies. ASAIO Trans, 1987;33:356-8.

26. Hasse C, Zielke A, Klöck G, et al., Isotransplantation of microencapsulated parathyroid tissue in rats. Exp Clin Endocrinol Diabetes, 1997;105:53-6.

27. Hasse C, Schlosser A, Klöck G, et al., [Heterologoustransplantation of human parathyroid glands after microencapsulation with clinically suitable alginate: long-term function with outimmuno suppression in the animal model]. Langenbecks Arch Chir Suppl Kongressbd, 1998;115(Suppl I):713-8.

28. Lin L, Song Y, Song C, et al., Success fulxeno transplantation of microencapsulated new born pig parathyroid cells in the treatment of hypoparathyroidism in rats. Chin Med J (Engl), 2003; 116: 1161-5.

29. Lee CH, Wang YJ, Kuo SM, et al., Microencapsulation of parathyroid tissue with photosensitive poly (Llysine) and short chain alginate-co-MPEG. Artif Organs, 2004;28:537-42.

30. Hwang SR, Seo DH, Byun Y, et al., Preparationand in vivo evaluation of an orally available entericmicroencapsulated parathyroid hormone (1-34)deoxycholic acid nanocomplex. Int J Nanomedicine, 2016;11:4231-46. 